\title{
Stock Price and Analyst Earnings Forecast around Product Recall
} Announcements

\author{
Yanxuan Chen $^{1} \&$ Nhut H. Nguyen ${ }^{1}$ \\ ${ }^{1}$ Department of Accounting and Finance, The University of Auckland, Auckland, New Zealand \\ Correspondence: Nhut H. Nguyen, Department of Accounting and Finance, The University of Auckland, \\ Auckland, New Zealand. Tel: 64-9-923-3326. E-mail: n.nguyen@auckland.ac.nz
}

\author{
Received: March 27, $2013 \quad$ Accepted: April 16, $2013 \quad$ Online Published: May 21, 2013 \\ doi:10.5539/ijef.v5n6p1 URL: http://dx.doi.org/10.5539/ijef.v5n6p1
}

\begin{abstract}
Product recalls have long been recognised to have an impact on firm value. We revisit this issue using more recent data across different industries. We also examine the recall impact on the the firm's expected performance using analyst' earnings forecasts. The results show that product recall announcements negatively affect stock prices and analysts' earnings forecasts. However, there is weak evidence on the market response between characteristics-based subsamples of recalls.
\end{abstract}

Keywords: product recall, analyst forecast, firm value

\section{Introduction}

Product recall has always been of concern to the public. As Gibson (1995) argued, product recalls are quantitatively and qualitatively important. They involve manufacturers, consumers, retailers, government regulators and the media. They may also involve unemployment, product line or plant closure, injury or death.

In recent years, product recalls due to quality problems have surged dramatically in different industries. The United States Consumer Product Safety Commission was involved in 221 recall cases covering roughly 8 million consumer product units in 1988. By 1993, the number of recalls increased to 367 covering approximately 28 million product units. Recently, the 2011 Consumer Reports report that at least 124.7 million products were recalled in 2010, and 26 deaths were associated with recalled products. Moreover, due to the increased globalization of production, increasing complexity of the products, greater demand for the safety and quality of a product, closer monitoring by the media and more regulation by government agencies, the trend is likely to continue (Berman, 1999). Although product recalls and their growth have long been recognized as important economic events (Smith, Thomas, \& Quelch, 1996), most people are unaware of them. A new poll released by the 2011 Consumer Reports concludes that, over the past three years, only one-fifth of American adults who purchased a recalled product, other than a car, were actually aware of it.

In this paper, we use 206 product recall announcements by 97 U.S. listed companies over the period 2000-2007 to examine the recall impact on firm value. Similar to previous literature, we first investigate stock price movement around the announcement date. We find that investors respond negatively to product recalls consistent with previous evidence. In addition, the negative stock price movement is significantly larger for recalls in the automotive industry for various event windows we use. However, the results are weak in differentiating the impact based on recall characteristics. They do not show any differential effect between recalls that involve death and those that do not. Voluntary recalls moderate the negativity of market response while recalls with the purpose of withdrawing the product out of the market worsen the return decrease. These results are, however, sensitive to the event window used.

Our contribution to the literature on product recalls also lies in the analysis of analyst forecast revisions. That is, we use the changes in analysts' earnings forecasts around the recall announcement date to assess if analysts also form a significantly negative view about the firm's future performance. If so, we expect analysts lower their forecasts for the firm's earnings in the current year. This analysis has never been done in previous studies. Results show that, on average, analysts indeed revise their earnings forecasts to a lower level after a recall is announced, which is consistent with the negative market response in stock price. However, there is no evidence that analyst revisions differ for various groups of recalls based on recall characteristics. 
The remainder of the paper is organised as follows. Section 2 provides a literature review. Section 3 discusses the data. The results are presented in Section 4. Section 5 concludes.

\section{Literature Review}

A product is removed from the market or a correction is made to the product because it is either defective or potentially harmful. Sometimes a company discovers a problem and recalls a product on its own; at other times a company recalls a product after regulators raise concerns. Several papers find evidence that shareholders' wealth is affected after a product recall, but the result is mixed. Pruitt and Peterson (1985) look into drug, electrical, food, rubber, toys and cosmetics industries and find that product recall is viewed as an unfavourable event and stock price responds significantly to it. Hoffer, Pruitt, and Reilly (1987) find that stock price reacts negatively in the short term to product recalls in the automobile industry. Barber and Darrough (1996) find that firms conducting a recall suffer a significant decrease in the stock price in the time immediately after the recall announcement date.

On the one hand, a recall may signal to the public the failure of the company's internal control over product quality (Brown, 2000). Therefore, recalls are costly to companies because they often entail consequential costs caused by damage to brand name and reduced trust in the manufacturer (Choi \& Lin, 2009; Korkofingas \& Ang, 2011). This is consistent with findings of negative impact on stock price. On the other hand, a number of studies (e.g. Minor \& Morgan, 2011) find that a recall announcement could actually be interpreted as indicative of the fulfilment of corporate social responsibility (CSR) and therefore could have a positive impact on firm value in terms of reputational improvement. Yaros and Wood (1979) suggest corporations have begun to be aware of the importance of acting beyond mere compliance with laws to embracing a more responsible attitude towards society because of the increased sophistication of consumers and interest in socially responsible investing. Indeed adopting CSR practices as a means of creating and maintaining greater competitive advantage and resilience in business. As reported by Brown (2000), the listing of companies in CSR indices has been proposed as a means to enhance corporate reputation, which is itself a valuable factor in determining an organisation's success.

Prior literature has argued for the relationship between CSR and firm performance energetically. Moskowitz (1972) selects 14 'high-CSR' firms, based on their positive responses to social problems and find there is a positive correlation between social and economic performance in the short term. However, Vance (1975) finds a negative correlation between CSR rankings and stock market performance which implies that recalls increase expense for socially responsible firms. Davidson and Worrell (1988) use public announcements of corporate illegalities as a proxy for social irresponsibility and find a negative impact on the shareholders' wealth. Rao and Hamilton (1996) examine how published reports of unethical behaviour by publicly traded and multinational firms in the U.S. impact their stock performance and find the actual stock returns are lower than the expected market adjusted returns for an appreciable period of time when unethical conduct is discovered and publicized. Cheah, Chan, and Chieng (2007) investigate the effect on shareholder wealth and the extent to which the adoption of CSR practices by pharmaceutical companies in U.K. and U.S. affect the market reaction to the product recall announcements. They find that U.S. investors respond differently to differences in the severity of the consequences of the recall where the CSR tradition is weak and that U.K. investors respond indifferently to the severity of the recall where CSR tradition is strong. The positive impact of the recall in terms of fulfilment of CSR adds to the mixed results of the impact of recalls on firm value.

Early research (e.g., Jarrell and Peltzman, 1985) focuses on automotive and pharmaceutical industries because product recalls in the automotive industry are consistently more frequent than in other industries and there is a public safety concern for recalls in drug industry. Davidson and Worrell (1992), and Pruitt and Peterson (1985) report that the number of automotive recalls by only the top three companies in automotive industry is already about twice as large as all other recalls combined. More recent papers examine product recalls in other industries. Salin and Hooker (2001) look at the food industry and find returns to shareholders falling immediately after the recall for the smallest firm in the study, but recalls by larger firms are inconsistently associated with large reductions in returns. Thomsen and McKenzie (2001) look at the meat and poultry industry and find significant shareholder losses when publicly traded food companies are implicated in a recall involving serious food safety hazards. They find no evidence that the stock market reacts negatively when less hazardous recalls are involved. Chen, Ganesan, and Liu (2009) examine the impact of strategies adopted by responsible firms during recalls of consumer goods and find proactive strategies have a more negative effect on firm value than passive strategies.

Regarding the magnitude of market responses to product recall announcements, Marcus, Swindler, and Zivney 
(1987) find the loss in the stock price is much larger than any reasonable measure of direct costs in the drug industry. Govindaraj, Jaggi, and Lin (2004) find that market losses are approximately equal to the near worst-case estimates of direct and indirect costs, litigation costs, regulation compliance costs and costs associated with future losses in sales and that this over-reaction is corrected as information on actual costs becomes available. Additionally, Chu, Lin, and Prather (2005) find that prices of securities immediately incorporate all available information once it is released to the market.

\section{Data}

Our sample of product recall announcements are hand collected from the Wall Street Journal (WSJ) from 1 January 2000 to 31 December 2007. Compared to the official recall announcements issued on the corresponding authorities' websites, WSJ is a popular source of recall information for the public. Our data collection and cross-check are as follows. Firstly, we obtain from the WSJ a list of companies that conducted product recalls during the period January 2000 through December 2007. The list includes 413 companies. Secondly, we check against the University of Chicago's Center for Research in Security Prices (CRSP) database to see if the companies are publicly traded on NYSE, AMEX or NASDAQ. We exclude companies that are not publicly traded on the above three exchanges due to the unavailability of their stock prices and analysts' forecasts. This reduces the sample to 97 companies.

We then search WSJ and collect the announcement dates and the characteristics that we are interested in from the announcements made by these 97 companies during the seven-year sample period. The characteristics of interest are industry, type of the recalled product, conductor of the recall (company itself or ordered by the relevant authority), severity of the reason for the recall (whether death is involved) and purpose of recall (whether the product is to be withdrawn from the market entirely). An announcement is deleted if the WSJ does not identify the manufacturer. The final sample includes 206 product recall announcements.

In this research the announcements collected from the WSJ are carefully checked against the relevant authorities' official announcements. We check all the recall announcements that are under regulation by Consumer Product Safety Commission (CPSC) against the official recall announcements on the CPSC website but only some of the announcements under regulation of Food and Drug Administration (FDA) and National Highway Traffic Safety Administration (NHTSA) are checked against those reported in their respective websites. CPSC-regulated product recall announcements are chosen to be checked thoroughly because the CPSC is responsible for the most diversified range of consumer products (Chen et al., 2009) and because only the CPSC has developed a systematic way to search historical recall announcements for corresponding companies. We check the date and the characteristics of the recall announcements, such as name of the recalling company and type of product being recalled, whether the recall is voluntary and whether the recall is triggered with death. Note that any incidents are reported either to the firm or to the CPSC; the general media is not aware of them. Most of the product recalls are announced one day after all official recall information has originated from the CPSC; some others are announced two days after. Characteristics reported in the official recall announcements on the CPSC website are the same as those disclosed in the WSJ announcements. For product recalls under the regulation of FDA and NHTSA, we randomly check 10 of WSJ announcements against these authorities' websites. This is due to the fact that unlike the CPSC website, FDA and NHTSA websites do not allow systematic download of announcements. The information from our random check is generally consistent with those in WSJ.

Financial data for the recalling firms are collected from CRSP database. They include stock price, market value, benchmark return and book to market ratio. Detailed analysts' forecasts are obtained from I/B/E/S database in WRDS.

\section{Empirical Results}

\subsection{Descriptive Statistics and Univariate Results}

Table 1 presents our sample of recalls classified by product type. Eighty seven out of 206 recalls are from the automotive industry. This represents $42 \%$ of the sample. Many recalls are also for food products, health care equipment and technology hardware products. There is only one product recall for leisure goods, media, and computer software products. Regarding characteristics of the recalls, 18 recalls involve death, 7 are withdrawals, and 8 recalls are ordered by the relevant authorities. 
Table 1. Sample of product recalls

\begin{tabular}{ll}
\hline Product type & $\mathrm{N}$ \\
\hline Aerospace & 2 \\
Automobiles \& Parts & 87 \\
Drug & 9 \\
Eye Care & 4 \\
Food & 27 \\
Health Care Equipment \& Services & 27 \\
Leisure Goods & 1 \\
Media & 1 \\
Personal Goods & 3 \\
Pharmaceuticals \& Biotechnology & 4 \\
Software \& Computer Services & 1 \\
Technology Hardware \& Equipment & 19 \\
Toys \& Game & 11 \\
Biologic Products & 2 \\
Home and Commercial Appliances & 8 \\
Total & 206 \\
\hline
\end{tabular}

Description: This table present the number of recalls classified by product type. The sample period is from 1 January 2000 to 31 December 2007.

Table 2 reports the mean and median abnormal returns for 31 days around the announcement date. Abnormal return is calculated as raw return on day $t$ minus the market-model expected return based on the estimation period of [t-271, t-21] days. Table 2 shows that the abnormal returns are statistically different from zero for only 5 out of 31 days around the announcement date. Importantly, it shows that product recalls, on average, are associated with a significant negative response from the market participants although it seems that the market responds one day before the actual announcement date. This average drop in price is about $1.5 \%$ significant at the $5 \%$ level. Figure 1 shows the pattern of the cumulative abnormal return around the announcement date. It shows a large drop on day $\mathrm{t}-1$ and some volatility for the post-announcement period.

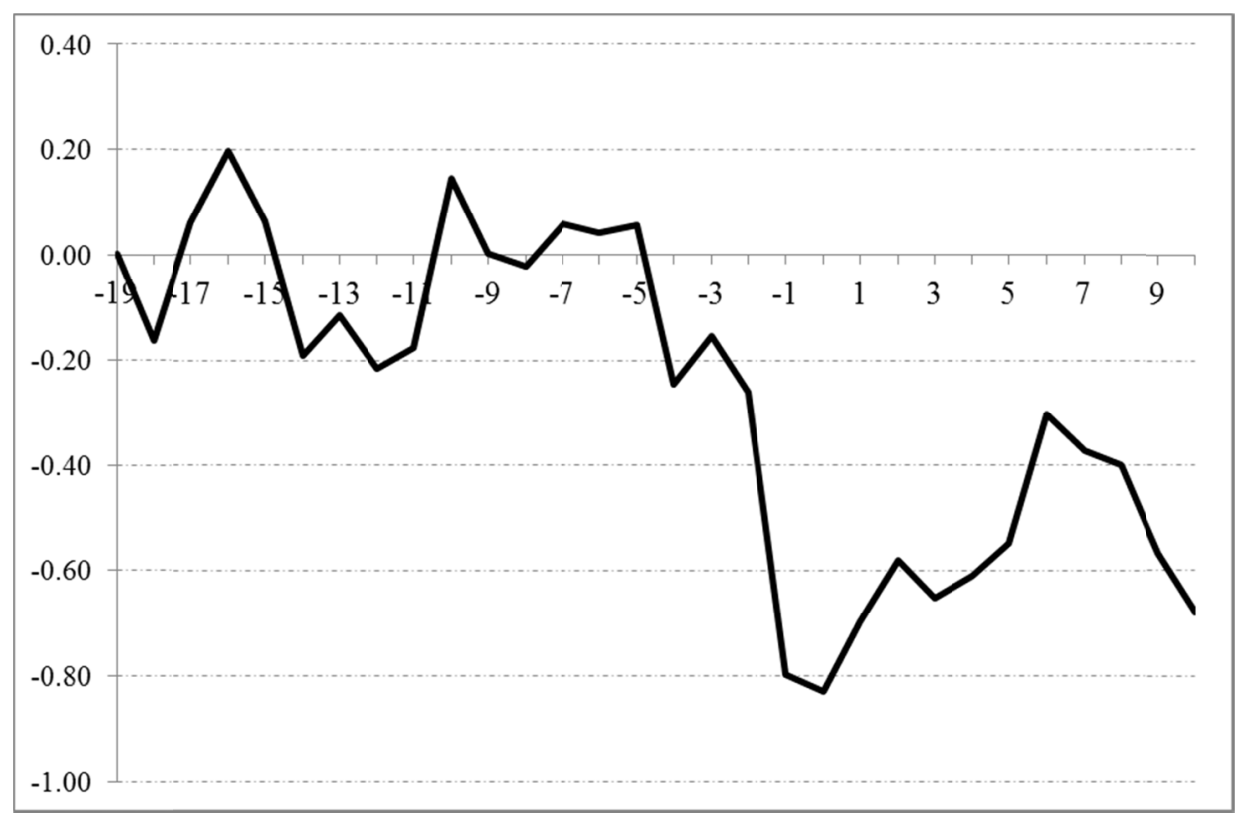

Figure 1. Cumulative abnormal returns around the recall announcement date 
Table 2. Abnormal returns around recall announcement dates

\begin{tabular}{|c|c|c|c|c|}
\hline Day & Median & Mean & $t$-statistic & \\
\hline-20 & -0.002 & -0.207 & $(-0.91)$ & \\
\hline-19 & -0.033 & -0.092 & $(-0.77)$ & \\
\hline-18 & -0.120 & -0.246 & $(-0.96)$ & \\
\hline-17 & 0.079 & 0.248 & $(0.79)$ & \\
\hline-16 & 0.045 & 0.176 & $(0.84)$ & \\
\hline-15 & -0.213 & -0.133 & $(-0.56)$ & \\
\hline-14 & -0.276 & -0.289 & $(-1.66)$ & * \\
\hline-13 & 0.041 & 0.085 & $(0.84)$ & \\
\hline-12 & -0.129 & -0.141 & $(-0.92)$ & \\
\hline-11 & 0.008 & 0.101 & $(-0.31)$ & \\
\hline-10 & 0.287 & 0.327 & (1.85) & $*$ \\
\hline-9 & -0.201 & -0.137 & $(-2.17)$ & $* *$ \\
\hline-8 & -0.048 & -0.047 & $(-0.64)$ & \\
\hline-7 & 0.013 & 0.090 & $(0.49)$ & \\
\hline-6 & -0.023 & -0.011 & $(-0.41)$ & \\
\hline-5 & -0.158 & 0.038 & $(-0.02)$ & \\
\hline-4 & -0.168 & -0.466 & $(-1.69)$ & $*$ \\
\hline-3 & -0.062 & 0.133 & $(0.56)$ & \\
\hline-2 & -0.197 & -0.318 & $(-1.14)$ & \\
\hline-1 & -0.137 & -1.445 & $(-2.42)$ & $* *$ \\
\hline 0 & 0.050 & 0.199 & $(0.17)$ & \\
\hline 1 & -0.028 & 0.168 & (1.53) & \\
\hline 2 & -0.005 & 0.027 & $(-0.08)$ & \\
\hline 3 & -0.106 & 0.100 & $(-0.28)$ & \\
\hline 4 & -0.040 & 0.032 & $(-0.13)$ & \\
\hline 5 & -0.061 & 0.851 & $(1.08)$ & \\
\hline 6 & 0.050 & 0.321 & $(1.40)$ & \\
\hline 7 & -0.099 & -0.135 & $(-1.21)$ & \\
\hline 8 & -0.224 & -0.040 & $(-0.37)$ & \\
\hline 9 & -0.095 & -0.185 & $(-0.64)$ & \\
\hline 10 & -0.022 & -0.179 & $(-1.11)$ & \\
\hline
\end{tabular}

Description: This table presents the mean and median abnormal returns around the recall announcement date. Abnormal return is calculated as the raw return on day $\mathrm{t}$ minus its expected return, which is estimated from a market model using day t-271 through day t-21 relative to the announcement date. The t-statistics is based on the Boehmer, Musumeci, and Poulsen's (1991) standardized cross-sectional test. ***, **, and * indicate significance at the $1 \%, 5 \%$, and 10\% levels, respectively. Sample period is from 1 January 2000 to 31 December 2007.

Table 3 reports the cumulative abnormal return (CAR) for the sample and subsamples for different event windows. Panel A shows that overall there is a significant decrease in share price around the product recall date. This decrease is statistically significant at the $5 \%$ level for the $[-1,0]$ and $[-5,+3]$ windows, and at the $10 \%$ level for the $[-20,+10]$ window. These results are broadly consistent with previous studies on the effect of product recalls. When we split the sample into automotive and non-automotive recalls we find in Panel B that the return decrease is not significantly different between the two groups although the $[-1,0]$ and $[-5,+3]$ CARs are significantly lower than zero for the non-automotive group.

Panel $\mathrm{C}$ of Table 3 shows that product recalls that involve death, i.e. hazard, exhibit significantly negative market response around the announcement date. The $[-1,0]$ and $[-5,+3]$ CARs are negative and significant at the $10 \%$ level. However, the difference in CAR is not significant for all three windows examined. The results in Panel D show that both voluntary recalls and non-voluntary recalls triggers negative stock returns around the announcement date, except the $[-5,+3]$ CAR for the voluntary group. With a much larger magnitude in market response, CARs for the non-voluntary recall group are statistically lower than those in the voluntary group except for the $[-1,0]$ window. None of the results in Panel E are statistically different from zero for the withdrawal and non-withdrawal groups. 
Table 3. CARs around recall announcement dates

\begin{tabular}{|c|c|c|c|c|c|c|c|c|c|}
\hline \multicolumn{10}{|c|}{ Panel A: All recalls } \\
\hline Day & \multicolumn{2}{|l|}{ Median } & Mean & \multicolumn{2}{|c|}{$t$-stat } & & & & \\
\hline$[-1,0]$ & \multicolumn{2}{|l|}{-0.191} & -1.247 & \multicolumn{2}{|c|}{$(-2.41)$} & $* *$ & & & \\
\hline$[-5,+3]$ & \multicolumn{2}{|l|}{-0.827} & -1.585 & \multicolumn{2}{|c|}{$(-2.15)$} & $* *$ & & & \\
\hline$[-20,+10]$ & \multicolumn{2}{|l|}{-1.448} & -1.213 & \multicolumn{2}{|c|}{$(-1.85)$} & $*$ & & & \\
\hline \multicolumn{10}{|c|}{ Panel B: Non-automotive vs. automotive recalls } \\
\hline & \multicolumn{3}{|c|}{ Non-automotive (1) } & \multicolumn{3}{|c|}{ Automotive (2) } & \multicolumn{3}{|l|}{ (1) - (2) } \\
\hline & Mean & t-stat & & Mean & t-stat & & Diff. mean & t-stat & \\
\hline$[-1,0]$ & -0.917 & $(-1.90)$ & * & -0.149 & $(-0.50)$ & & -0.768 & $(-1.22)$ & \\
\hline$[-5,+3]$ & -1.201 & $(-2.02)$ & $* *$ & -0.010 & $(0.15)$ & & -1.191 & $(-1.53)$ & \\
\hline$[-20,+10]$ & -0.367 & $(-0.96)$ & & -0.941 & $(-1.28)$ & & 0.574 & $(0.27)$ & \\
\hline \multicolumn{10}{|c|}{ Panel C: Hazard vs. non-hazard recalls } \\
\hline & \multicolumn{3}{|c|}{ Non-hazard (1) } & \multicolumn{3}{|c|}{ Hazard (2) } & \multicolumn{3}{|l|}{$(1)-(2)$} \\
\hline & Mean & t-stat & & Mean & t-stat & & Diff. mean & t-stat & \\
\hline$[-1,0]$ & -0.464 & $(-1.34)$ & & -1.792 & $(-1.68)$ & $*$ & 1.328 & $(1.33)$ & \\
\hline$[-5,+3]$ & -0.457 & $(-1.04)$ & & -3.014 & $(-1.79)$ & * & 2.557 & $(1.40)$ & \\
\hline$[-20,+10]$ & -0.380 & $(-1.51)$ & & -3.251 & $(-0.40)$ & & 2.871 & $(-0.01)$ & \\
\hline \multicolumn{10}{|c|}{ Panel D: Voluntary vs. non-voluntary recalls } \\
\hline & \multicolumn{3}{|c|}{ Non-voluntary (1) } & \multicolumn{3}{|c|}{ Voluntary (2) } & \multicolumn{3}{|l|}{ (1) - (2) } \\
\hline & Mean & t-stat & & Mean & t-stat & & Diff. mean & t-stat & \\
\hline$[-1,0]$ & -4.109 & $(-1.87)$ & $*$ & -1.210 & $(-2.16)$ & $* *$ & -2.899 & $(-0.71)$ & \\
\hline$[-5,+3]$ & -12.419 & $(-2.59)$ & $* *$ & -0.871 & $(-1.64)$ & & -11.548 & $(-2.50)$ & $* *$ \\
\hline$[-20,+10]$ & -29.547 & $(-3.05)$ & $* *$ & -0.607 & $(-1.68)$ & * & -28.940 & $(-3.49)$ & $* * *$ \\
\hline \multicolumn{10}{|c|}{ Panel E: Withdrawal vs. non-withdrawal recalls } \\
\hline & \multicolumn{3}{|c|}{ Non-withdrawal (1) } & \multicolumn{3}{|c|}{ Withdrawal (2) } & \multicolumn{3}{|l|}{$(1)-(2)$} \\
\hline & Mean & t-stat & & Mean & t-stat & & Diff. mean & t-stat & \\
\hline$[-1,0]$ & -0.510 & $(-1.59)$ & & -2.856 & $(-1.02)$ & & 2.346 & $(0.93)$ & \\
\hline$[-5,+3]$ & -0.505 & $(-1.04)$ & & -6.456 & $(-1.69)$ & & 5.951 & $(1.59)$ & \\
\hline$[-20,+10]$ & -0.715 & $(-1.49)$ & & 2.586 & $(-0.41)$ & & -3.301 & $(0.27)$ & \\
\hline
\end{tabular}

Description: This table presents the mean cumulative abnormal returns around the recall announcement date. Abnormal return is calculated as described in Table 2. Automotive includes recalls in the automotive industries. Hazard includes recalls that involve injury or death. Recalls that are initiated by firms themselves are classified as voluntary. Recalls to withdraw the product entirely out of the market are classified as withdrawal. The t-statistics is based on the Boehmer, Musumeci, and Poulsen's (1991) standardized cross-sectional test. ***, **, and * indicate significance at the $1 \%, 5 \%$, and $10 \%$ levels, respectively. Sample period is from 1 January 2000 to 31 December 2007.

\subsection{Multivariate Regression Results}

In Table 4 we report the OLS regression results with the dependent variable being one of the cumulative abnormal returns in Table 3. The independent variables are also in Table 3 together with firm-specific characteristics such as the size of the firm's business, $\operatorname{Ln}(\mathrm{Sale})$, return volatility, RETVOL, measured as the standard deviation of the residuals from the market model over the $[-271,-21]$ period, and return on assets, ROA, in most recent year to proxy for the firm growth.

The results for specification (1) shows that the intercept is negative and significant only for the shorter windows, $[-1,0]$ and $[-5,+3]$. This indicates that after controlling for firm-specific characteristics, product recalls are generally a bad news to the market and investors respond accordingly. When hazard dummy is introduced into the regression, specification (2), its coefficient is negative as expected but is not significant across all windows. This result is consistent with the univariate result in Panel $\mathrm{C}$ of Table 3. When voluntary dummy is used in specification (3), its coefficient is positive and significant at the $1 \%$ level for the $[-20,+10]$ window. This result is consistent with those in Panel D of Table 3 and indicates that voluntary recalls generally receive a less negative response by the market than those recalls that are ordered by the relevant government agency. The voluntary dummy is not significant for the shorter windows. The withdrawal dummy in specification (4) exhibits a negative value as expected. However, it is significant at the $5 \%$ level only when $[-5,+3]$ CAR is used as the dependent variable. The result is generally improved from its univariate one in Panel E of Table 3 after controlling for firm characteristics. It indicates that if the product is withdrawn from the market entirely, the 
recall announcement is seen as more negative for the firm's future value. As such, investors respond more negatively. Unlike the insignificant results for the automotive industry in Table 3, Panel B, the results in specification (5) shows that product recalls in the automotive industry are apparently associated with significantly larger negative returns compared to other industries in the sample. The automotive dummy is negative and significant in all three event windows.

The results for control variables show that larger firm size in term of sales appear to moderate the negative impact of product recalls. The $\operatorname{Ln}(\mathrm{Sale})$ coefficient is positive and significant in 11 out of 15 specifications across the three windows. There are weak evidence that product recalls hurt growth firms more than less growth firms. The ROA coefficient is negative in 11 out of 15 specifications but only significant in 6 regressions, especially when the $[-20,+10]$ window is used. The stock return volatility does not seem to have a significant impact on the cumulative abnormal return around the announcement date. None of the RETVOL coefficient is statistically significant.

Table 4. OLS regression results

\begin{tabular}{|c|c|c|c|c|c|c|c|c|c|c|c|c|c|c|c|}
\hline & \multicolumn{5}{|c|}{$[-1,0]$ CAR } & \multicolumn{5}{|l|}{$[-5,3]$ CAR } & \multicolumn{5}{|c|}{$[-20,10]$ CAR } \\
\hline & (1) & (2) & (3) & (4) & (5) & (1) & (2) & (3) & (4) & (5) & (1) & (2) & (3) & (4) & (5) \\
\hline \multirow[t]{2}{*}{ Intercept } & -3.81 & -3.52 & -3.46 & -3.28 & -5.92 & -7.36 & -6.81 & -8.74 & -5.69 & -10.88 & -3.40 & -2.83 & -10.59 & -3.39 & -15.04 \\
\hline & $(-2.31)^{* *}$ & $(-2.09)^{* *}$ & $(-2.03)^{* *}$ & $(-1.84)^{*}$ & $(-2.89)^{* * *}$ & $*(-2.65)^{* * *}$ & $(-2.37)^{* *}$ & $(-2.63)^{* * *}$ & $*(-1.94)^{*}$ & $(-3.29)^{* * *}$ & $*(-0.57)$ & $(-0.48)$ & $(-1.77)^{*}$ & $(-0.57)$ & $(-2.15)^{* *}$ \\
\hline \multirow[t]{2}{*}{ Hazard } & & -0.91 & & & & & -1.73 & & & & & -1.82 & & & \\
\hline & & $(-0.91)$ & & & & & $(-0.92)$ & & & & & $(-0.54)$ & & & \\
\hline \multirow[t]{2}{*}{ Voluntary } & & & -0.52 & & & & & 2.06 & & & & & 10.68 & & \\
\hline & & & $(-0.42)$ & & & & & $(0.84)$ & & & & & $(3.00)^{* * *}$ & & \\
\hline \multirow[t]{2}{*}{ Withdrawal } & & & & -1.75 & & & & & -5.51 & & & & & -0.03 & \\
\hline & & & & $(-0.80)$ & & & & & $(-1.98)^{* *}$ & & & & & $(-0.01)$ & \\
\hline \multirow[t]{2}{*}{ Automotive } & & & & & -1.65 & & & & & -2.76 & & & & & -9.12 \\
\hline & & & & & $(-1.92)^{*}$ & & & & & $(-2.00)^{* *}$ & & & & & $(-2.77)^{* * *}$ \\
\hline \multirow[t]{2}{*}{ Ln(Sale) } & 0.37 & 0.35 & 0.39 & 0.34 & 0.67 & 0.62 & 0.59 & 0.58 & 0.53 & 1.12 & 0.21 & 0.17 & -0.04 & 0.21 & 1.84 \\
\hline & $(2.84)^{* * *}$ & $(2.61)^{* * *}$ & $(2.75)^{* * *}$ & $(2.43)^{* *}$ & $(3.06)^{* * *}$ & $(2.89)^{* * *}$ & $(2.61)^{* * *}$ & $(2.60)^{* * *}$ & $(2.34)^{* *}$ & $(3.43)^{* * *}$ & $(0.48)$ & $(0.39)$ & $(-0.09)$ & $(0.48)$ & $(2.57)^{* *}$ \\
\hline \multirow[t]{2}{*}{ RETVOL } & -0.28 & -0.29 & -0.27 & -0.33 & -0.25 & 0.19 & 0.17 & 0.14 & 0.03 & 0.25 & 1.00 & 0.99 & 0.77 & 1.00 & 1.20 \\
\hline & $(-0.89)$ & $(-0.92)$ & $(-0.85)$ & $(-1.06)$ & $(-0.80)$ & $(0.30)$ & $(0.27)$ & $(0.22)$ & $(0.04)$ & $(0.40)$ & $(0.83)$ & $(0.81)$ & $(0.64)$ & $(0.82)$ & $(1.00)$ \\
\hline \multirow[t]{2}{*}{ ROA } & 0.01 & 0.01 & 0.01 & 0.00 & -0.02 & -0.01 & -0.01 & -0.01 & -0.03 & -0.05 & -0.19 & -0.18 & -0.19 & -0.19 & -0.33 \\
\hline & $(0.46)$ & $(0.57)$ & $(0.44)$ & $(0.10)$ & $(-0.73)$ & $(-0.40)$ & $(-0.22)$ & $(-0.39)$ & $(-1.01)$ & $(-1.72)^{*}$ & $(-1.93)^{*}$ & $(-1.86)^{*}$ & $(-2.09)^{* *}$ & $(-1.98)^{* *}$ & $(-3.51)^{* * *}$ \\
\hline Adj. R2 & 0.07 & 0.07 & 0.07 & 0.07 & 0.08 & 0.03 & 0.03 & 0.02 & 0.04 & 0.03 & 0.03 & 0.02 & 0.05 & 0.02 & 0.06 \\
\hline $\mathrm{N}$ & 206 & 206 & 206 & 206 & 206 & 206 & 206 & 206 & 206 & 206 & 206 & 206 & 206 & 206 & 206 \\
\hline
\end{tabular}

Description: This table presents the OLS regression results of cumulative abnormal returns on recall characteristics controlling for firm characteristics. Hazard is a dummy variable equal 1 for recalls that involve injury or death, and zero otherwise. Voluntary is a dummy with a value of 1 for recalls that are initiated by firms, and zero otherwise. Withdrawal dummy has a value of 1 if a recalled product is to be withdrawn entirely out of the market, and zero otherwise. Automotive dummy equals 1 for recalls in the automotive industries, and zero otherwise. The t-statistics is corrected for heteroskedasticity following White (1980).***,**, and * indicate significance at the $1 \%, 5 \%$, and $10 \%$ levels, respectively. Sample period is from 1 January 2000 to 31 December 2007.

\subsection{Analyst Revision of Earnings Forecasts}

The results in Table 3 and 4 are apparently consistent with expectations and the findings reported in the literature. However, the existing literature has never examined whether analysts generally have the same view as market participants regarding product recalls. If analysts see that a product recall would significantly affect the firm's performance in the future, they would revise their earnings forecasts to a lower level.

We use $\mathrm{I} / \mathrm{B} / \mathrm{E} / \mathrm{S}$ detail file to calculate the mean analyst annual earnings forecasts 60 days before and 60 days after the recall announcement date. Then we calculate the change in the mean analyst forecasts by taking the difference between the mean forecast post- and pre-announcement and divide this difference by the stock price on day t-61 (the results for median analyst forecasts are similar and not reported here). We test if this change is statistically different from zero. The univariate results are reported in Table 5 for the overall sample and the sub-samples. The results show that overall analysts revise their earnings forecasts for recalling firms. This downward revision appears to be statistically larger for firms in the automotive industry than those in other industries. However, there are no significant differences in analyst forecast revision between groups of other recall characteristics: hazard, voluntary and withdrawal. 
Table 5. Analyst earnings forecast revisions

\begin{tabular}{llll}
\hline & Mean & $t$-statistics & \\
\hline All & -0.007 & $(-2.84)$ & $* * *$ \\
Non-automotive (1) & -0.003 & $(-1.30)$ & $* *$ \\
Automotive (2) & -0.012 & $(-2.56)$ & $*$ \\
(1) - (2) & 0.009 & $(1.82)$ & $* * *$ \\
Non-hazard (3) & -0.006 & $(-2.64)$ & \\
Hazard (4) & -0.009 & $(-1.05)$ & $* *$ \\
(3) - (4) & 0.003 & $(0.31)$ & \\
Non-voluntary (5) & -0.030 & $(-1.56)$ & $* * *$ \\
Voluntary (6) & -0.006 & $(-2.51)$ & \\
(5) - (6) & -0.024 & $(-1.24)$ & \\
Non-withdrawal (7) & -0.006 & $(-2.63)$ & \\
Withdrawal (8) & -0.025 & $(-1.10)$ & \\
(7) - (8) & 0.019 & $(0.82)$ & \\
\hline
\end{tabular}

Description: This table presents the change in analyst earnings forecasts around the recall announcement date. This change is calculated as the difference in the mean forecasts between 60 days before and after the announcement date scaled by the stock price on day t-61. Automotive includes recalls in the automotive industries. Hazard includes recalls that involve injury or death. Recalls that are initiated by firms themselves are classified as voluntary. Recalls to withdraw the product entirely out of the market are classified as withdrawal. ***, **, and $*$ indicate significance at the $1 \%, 5 \%$, and $10 \%$ levels, respectively. Sample period is from 1 January 2000 to 31 December 2007.

In Table 6, we report the regression results using this analyst revision as the dependent variable. All independent and control variables are the same as in Table 4. The results are consistent with Table 5 in that analyst lower their earnings forecasts for recalling firms regardless of their firm characteristics as in specification (1). Moreover, their revision does not seem to be different between groups of recalling firms. None of the dummy variables, hazard, voluntary, withdrawal, and automotive exhibits a significant coefficient. Similar to Table 4, firm size, $\mathrm{Ln}($ Sale), apparently moderate the downward revision. However, the ROA variable has a positive sign and significant across all specifications, which suggests that growth is also a moderating factor in analyst forecast revision. This is inconsistent with the results for ROA in Table 4.

Table 6. OLS regression results for analyst forecast revisions

\begin{tabular}{|c|c|c|c|c|c|c|c|c|c|c|}
\hline & $(1)$ & & $(2)^{\prime}$ & & (3) & & (4) & & (5) & \\
\hline Intercept & $\begin{array}{l}-0.09 \\
(-2.90)\end{array}$ & $* * *$ & $\begin{array}{l}-0.09 \\
(-2.87)\end{array}$ & $* * *$ & $\begin{array}{l}-0.10 \\
(-3.04)\end{array}$ & $* * *$ & $\begin{array}{l}-0.08 \\
(-2.93)\end{array}$ & $* * *$ & $\begin{array}{l}-0.12 \\
(-3.34)\end{array}$ & $* * *$ \\
\hline Hazard & & & $\begin{array}{l}0.00 \\
(-0.61)\end{array}$ & & & & & & & \\
\hline Voluntary & & & & & $\begin{array}{l}0.01 \\
(0.53)\end{array}$ & & & & & \\
\hline Withdrawal & & & & & & & $\begin{array}{l}-0.03 \\
(-1.62)\end{array}$ & & & \\
\hline Automotive & & & & & & & & & $\begin{array}{l}0.00 \\
(1.49)\end{array}$ & \\
\hline $\operatorname{Ln}($ Sale $)$ & $\begin{array}{l}0.01 \\
(2.40)\end{array}$ & $* *$ & $\begin{array}{l}0.01 \\
(2.37)\end{array}$ & $* *$ & $\begin{array}{l}0.01 \\
(2.18)\end{array}$ & $* *$ & $\begin{array}{l}0.01 \\
(2.37)\end{array}$ & $* *$ & $\begin{array}{l}0.01 \\
(2.87)\end{array}$ & $* * *$ \\
\hline RETVOL & $\begin{array}{l}0.00 \\
(0.70)\end{array}$ & & $\begin{array}{l}0.00 \\
(0.70)\end{array}$ & & $\begin{array}{l}0.00 \\
(0.63)\end{array}$ & & $\begin{array}{l}0.00 \\
(0.41)\end{array}$ & & $\begin{array}{l}0.00 \\
(0.82)\end{array}$ & \\
\hline ROA & $\begin{array}{l}0.00 \\
(3.59)\end{array}$ & $* * *$ & $\begin{array}{l}0.00 \\
(3.60)\end{array}$ & $* * *$ & $\begin{array}{l}0.00 \\
(3.52)\end{array}$ & $* * *$ & $\begin{array}{l}0.00 \\
(3.83)\end{array}$ & $* * *$ & $\begin{array}{l}0.00 \\
(3.30)\end{array}$ & $* * *$ \\
\hline Adj. R2 & 0.37 & & 0.36 & & 0.37 & & 0.37 & & 0.37 & \\
\hline $\mathrm{N}$ & 179 & & 179 & & 179 & & 179 & & 179 & \\
\hline
\end{tabular}

Description: This table presents the change in analyst earnings forecasts around the recall announcement date. This change is calculated as the difference in the mean forecasts between 60 days before and after the announcement date scaled by the stock price on day t- 61 . Hazard is a dummy variable equal 1 for recalls that involve injury or death, and zero otherwise. Voluntary is a dummy with a value of 1 for recalls that are initiated by firms, and zero otherwise. Withdrawal dummy has a value of 1 if a recalled product is to be withdrawn entirely out of the market, and zero otherwise. Automotive dummy equals 1 for recalls in the automotive industries, and zero otherwise. The t-statistics is corrected for heteroskedasticity following White (1980).***,**, and * indicate significance at the $1 \%, 5 \%$, and $10 \%$ levels, respectively. Sample period is from 1 January 2000 to 31 December 2007. 


\section{Conclusion}

In this paper we examine the effect of US product recalls for the period 2000-2007 by firms in a number of industries. The recall effect on firm value is assessed using the stock price movement around the announcement date as normally done in the existing literature in this topic. We also look at whether analysts revise their earnings forecasts after the recall announcement. We find that market participants lower their expectations about the firm's future performance resulting in a negative abnormal return around the announcement date. We also find that recalls for the automotive industry exhibit larger negative responses by the market than those in other industries. The evidence on the differential effect of recalls based on their characteristics such as hazard, voluntary, and withdrawal is weak and dependent on the event windows used. Finally, we find that, on average, analysts also revise their earnings forecasts downward but there is no significance difference in their revision between firms in different sub-groups.

\section{References}

Barber, B. M., \& Darrough, M. N. (1996). Product reliability and firm value: The experience of American and Japanese automakers, 1979-1992. The Journal of Political Economy, 104(5), 1084-2000. http://www.jstor.org/stable/2138953

Berman, B. (1999). Planning for the inevitable product recall. Business Horizons, 42(2), 69-78. http://dx.doi.org/10.1016/S0007-6813(99)80011-1

Brown, J. (2000). Managing corporate reputation from Turnbull, internal control and wider aspects of risk. Retrieved from http://www.acca.org.uk/pdfs/environment/turnbull.pdf

Cheah, E. T., Chan, W. L., \& Chieng, C. L. (2007). The corporate social responsibility of pharmaceutical product recalls: An empirical examination of U.S. and U.K. markets. Journal of Business Ethics, 76, 427-449. http://dx.doi.org/10.1007/s10551-006-9292-1

Chen, Y., Ganesan, S., \& Liu, Y. (2009). Does a firm's product-recall strategy affect its financial value? An examination of strategic alternatives during product-harm crises. Journal of Marketing, 73, 214-226. http://dx.doi.org/10.1509/jmkg.73.6.214

Choi, Y., \& Lin, Y. H. (2009). Consumer response to crisis: Exploring the concept of involvement in Mattel product recalls. Public Relations Review, 35(1), 18-22. http://dx.doi.org/10.1016/j.pubrev.2008.09.009

Chu, T. H., Lin, C. C., \& Prather, L. J. (2005). An extension of security price reactions around product recall announcements. Quarterly Journal of Business and Economics, 44(3/4), 33-48. http://www.jstor.org/stable/40473403

$\begin{array}{llll}\text { Consumer } & \text { Reports. } & \text { (2011). } & \text { Retrieved }\end{array}$ http://www.consumerreports.org/cro/magazine-archive/2010/january/january-2010-toc.htm

Davidson, W. N., \& Worrell, D. L. (1988). The impact of announcements of corporate illegalities on shareholder returns. Academy of Management Journal, 31(1), 195-200. http://dx.doi.org/10.2307/256506

Davidson, W. N., \& Worrell, D. L. (1992). Research notes and communications: The effect of product recall announcements on shareholder wealth. Strategic Management Journal, 13(6), 467-473. http://dx.doi.org/10.1002/smj.4250130606

Gibson, D. C. (1995). Public relations considerations of consumer product recall. Public Relations Review, 21, 225-240. http://dx.doi.org/10.1016/0363-8111(95)90023-3

Govindaraj, S., Jaggi, B., \& Lin, B. (2004). Market overreaction to product recall revisited: The case of Firestone tires and the Ford Explorer. Review of Quantitative Finance and Accounting, 23, 31-54. http://dx.doi.org/10.1023/B:REQU.0000037063.91860.87

Hoffer, G. E., Pruitt, S. W., \& Reilly, R. J. (1987). Automotive recalls and informational efficiency. The Financial Review, 22(4), 433-441. http://dx.doi.org/10.1111/j.1540-6288.1987.tb01265.x

Jarrell, G., \& Peltzman, S. (1985). The impact of product recalls and the wealth of sellers. Journal of Political Economy, 93(3), 512-536. http://www.jstor.org/stable/1832006

Korkofingas, C., \& Ang, L. (2011). Product recall, brand equity, and future choice. Journal of Marketing Management, 27(9-10), 959-975. http://dx.doi.org/10.1080/0267257X.2011.560717

Marcus, R. D., Swindler, S., \& Zivney, T. L. (1987). An explanation of why shareholders' losses are so large after drug recalls. Managerial and Decision Economics, 8(14), 295-300. 
http://dx.doi.org/10.1002/mde.4090080405

Minor, D., \& Morgan, J. (2011). CSR as reputation insurance: Primum on nocere. California Management Review 53(3), 40-59.

Moskowitz, M. (1972). Choosing socially responsible stocks. Business and Society Review, 1, 71-75.

Pruitt, S. W., \& Peterson, D. R. (1985). Security price reactions around product recall announcements. Journal of Financial Research, 9(2), 113-122. http://dx.doi.org/ 10.1111/j.1540-6288.1985.tb00277.x

Rao, S., \& Hamilton, J. B. (1996). The effect of published reports of unethical conduct on stock prices. Journal of Business Ethics, 15(12), 1321-1330. http://dx.doi.org/10.1007/BF00411817

Salin, V., \& Hooker, N. H. (2001). Stock market reaction to food recalls. Review of Agricultural Economics, 23(1), 33-46. http://dx.doi.org/10.1111/1058-7195.00044

Smith, N. C., Thomas, R. J., \& Quelch, J. A. (1996). A strategic approach to managing product recalls. Harvard Business Review, 74, 102-112. 